\title{
An econometric analysis of the macroeconomic determinants impact of gross domestic product (GDP) in Bangladesh
}

Mohammad Mushfiqul Haque Mukit

Department of Economics

Jahangirnagar University

Dhaka, Bangladesh.

ORCID: 0000-0002-7956-484X

E-mail: mushfiq.mukit@gmail.com 


\title{
Resumen
}

La investigación muestra que el Producto Interno Bruto (PIB) de Bangladesh tiene una relación causal con las exportaciones, las importaciones y la inflación. El estudio también revela que el tema de las exportaciones, las importaciones y la inflación se ha convertido en un arma vital para el crecimiento del Producto Interno Bruto (PIB) de Bangladesh, aportando tanto desarrollo tecnológico como inversión de capital y conocimiento del capital humano necesarios para el crecimiento económico. Bangladesh es un país en desarrollo y su economía se ha visto afectada por el déficit comercial desde sus inicios. De acuerdo con esta visión, este trabajo tiene como objetivo estudiar la relación entre las exportaciones, la inflación de las importaciones y el crecimiento económico mediante la prueba de cointegración y del Modelo Vector Autorregresivo (VAR). El análisis empírico se ha realizado utilizando datos secundarios anuales para el año 1982-2019. Los resultados obtenidos concluyeron que la serie estaba presente y que el modelo de regresión era significativo. Según los resultados, las exportaciones tuvieron una relación positiva pero no significativa con el PIB. Las importaciones, por otro lado, tenían una relación insignificante y negativa con el PIB. La inflación es una relación significativa y positiva con el PIB.

\begin{abstract}
The research shows that Bangladesh's Gross Domestic Product (GDP) has a causal relationship with exports, imports, and inflation. The study also reveals that the issue of export, import, and inflation has become a vital weapon of Gross Domestic Product (GDP) growth for Bangladesh, bringing in technological development as well as capital investment and human capital knowledge alike needed for economic growth. Bangladesh is a developing country and its economy has been hit by the trade deficit since its inception. According to this view, this paper purposes to study the relationship to export, import inflation, and economic growth by the cointegration and the Vector Autoregressive Model (VAR) test. The empirical analysis has been conducted by using annual secondary data for the year 1982-2019. The results obtained concluded that the series was present and that the regression model was significant. Based on the results, exports had a positive but not significant relationship to GDP. Imports, on the other hand, had an insignificant and negative relationship to GDP. Inflation is a significant and positive relationship to GDP.
\end{abstract}

Keywords: Exports, Import, Inflation and GDP.

JEL classification: B22, B23, E24, E26, E31, J24, R23. 


\subsection{INTRODUCTION}

The main purpose of this report is to analyze the relationship between export, import, inflation and GDP in order to provide a clear indication of the hypothesis regarding the country's position on whether or not it is beneficial to concentrate on export. The right assumption is based on the knowledge that we have obtained. One of the most critical determinants of economic growth is GDP. Export, import, inflation, and GDP has significant relationships.

Exports are one of the key sources of foreign exchange earnings, reducing the burden on the balance of payments and generating jobs. The argument concerning the position of exports as one of GDP's key drivers is not new. It is rooted in Adam Smith and David Ricardo's classical economic theory, who argued that foreign trade plays a major role in GDP. In foreign trade, the neoclassical approach stresses the importance of competitive advantages. Given the scarcity of resources and development factors in the economy, each nation maximizes its wealth through the most effective action

Fast economic growth is a key aim for many countries. Economic development, however, causes detrimental consequences, including the depletion of natural resources and growing differences between rich and poor (Tinh, 2012). Furthermore, erratic gross domestic product (GDP) growth leads to a rise in poverty and a decline in a country's development in health and education (Aziz and Azmi, 2017). Bangladesh is a country that is developing. It has massive natural properties. The lack of money and technology, the proper use of our natural resources, could not be adequately utilized. As a result, to alleviate our demands, we have to rely on foreign trade to import industrial goods and raw materials.

Both economic and non-economic factors decide imports. Imports are a potential tool for the economic development of Bangladesh and can play an important role in achieving the socio-economic goals of the country, including poverty reduction goals. As a lower-middleincome country like Bangladesh, imports will play an important role in rising physical resources, building production capacity and integrating the national economy into the global economy.

Inflation is characterized as a rise in the general price level on a continuous basis. Inflation is a sign of GDP growth, but GDP is impaired by high inflation and GDP is negatively impacted. As costs, income, and jobs decrease, even zero inflation is detrimental to other sectors of GDP.

\subsection{OBJECTIVES OF THE STUDY}

The main objective of this study is to examine the effects of Bangladesh's exports, imports and inflation on GDP. I found several other questions and tried to work out the answers to the goals. The basic aims of this study to accomplish this are:

- Find out the relative value of import determinants.

- Estimate an understanding of the existence and relative significance of export determinants. 
- To classify the relative value of inflation determinants.

\subsection{RESEARCH QUESTION \& HYPOTHESIS}

$H 1$. Is there any significant relationship between export and GDP?

$H 2$. Is there any significant relationship between imports and GDP?

$H 3$. Is there any significant relationship between inflation and GDP?

\subsection{BANGLADESH'S EXPORTS, IMPORTS, ECONOMIC DEVELOPMENT}

One of the most important problems in economic debate is the pace of a nation's economic growth. By promoting exports of goods and services, a nation could accelerate the rate of economic growth. Import volumes are negatively linked to their relative prices and vary positively in terms of aggregate demand (real GDP growth). The higher relative price leads to replacement away from imports, which necessarily reduces the dollar value as volumes decrease, imports. Remittances were used to fund the importation of money, for industrial production, products and raw materials (Ahmed \& Uddin, 2009). The manufacturing of garments is considered the country's highest foreign exchange earning industry (US\$8.228 billion in 2013-14). However, if the cost of importing raw materials is changed, then the net income from the remittances of migrant workers is greater than that of the clothing industry (Ahmed \& Uddin, 2009). However if the unofficial flow of remittances were to be taken into account, their contribution to GDP would undoubtedly be much higher. And, the rise in Taka (Bangladeshi Currency) 1 remittances would result in an increase of Tk 3.33 in national income.

\subsection{LITERATURE REVIEW}

Several research studies have been carried out by renowned researchers on various facets of export, import, and economic growth in Bangladesh and throughout the world. An effort was made to study the latest literature available on exports, imports, and economic development. A nation's pace of economic growth is one of the most significant topics of economic debate.

After the revolutionary era, Atrkar Roshan Sedigheh (2008) created a report on export expansion and economic growth in Iran. The findings of this study confirm the relation between these variables after the revolutionary time in Iran. Velnampy. T, Achchuthan (2013); Based on the overall analysis, exports and imports have an important positive relationship in the Sri Lankan context, and both exports and imports have a major effect on economic growth as well.

Another study conducted by Murat Çetinkaya and Savas Erdogan (2010) checked the relation between two figures using VAR Analysis to import exports. According to the analysis, the causality relationship between these variables was established, the variable import affected GDP, and the variable export was influenced by GDP. Two-way causality relationships released jointly between export and import. Similarly, the consequences of causality coincide with the test for variance decomposition.

Why do you research Bangladesh's Export Led Development (ELG)? The author has attempted to evaluate the relationship between exports, imports and economic growth in 
Bangladesh. ELG with remittance as a component was not included in any other previous studies. During the eighties and early nineties, Bangladesh underwent several trade based institutional reforms. ELG with remittance as a component was not included in any other previous studies. During the eighties and early nineties, Bangladesh underwent several trade based institutional reforms. This has had an impact on the overall trend of trade and economic development. In a multivariate context, Love and Chandra (2005) used annual GDP, export and import data to investigate the export-led growth hypothesis for Bangladesh and found short and long-term unidirectional causality from income to exports. Using annual data from 1960 to 2003, Mukit \& Islam (2018); Clarke and Ralhan (2005) find support for the causal nexus between export and development in Bangladesh. They claim that ancillary variables imply a causal nexus between exports and GDP when causality is viewed over a time horizon.

The export-led growth (ELG) hypothesis for five South Asian countries, including Bangladesh, was tested by Shirazi and Manap (2005) using cointegration and multivariate Granger Causality tests. They found feedback effects between exports and GDP and imports and GDP for Bangladesh.

In this research, Rahmaddi \& Ichihashi (2011) used a causality strategy focused on a multivariate model of error correction. The study revealed the importance to the Indonesian economy of both exports and GDP. Furthermore no proof of a positive causal relationship between intermediate imports and GDP per capita was found by the researchers. In the context of 1987, Erbaykal and Okuyan (2011) examined the link between inflation and GDP in Turkey: 1-2006: 2 info. In the long term, an established binding test has examined the presence of these two variables.

Yuhong Li (2010) performed integration studies with data on imports, exports, and GDP, and the findings indicate that import growth has added significantly to China's GDP, while export growth has done the reverse. Ullah S. (2009) examined export-led development in Pakistan using econometric techniques using time series from 1970 to 2008. The results of this study indicate that the growth of exports contributes to GDP.

In the period 1980-2010, Jayathileke and Rathnayake (2013) studied the relation between inflation and economic growth in three Asian countries: China, India and Sri Lanka. The data was applied to the Unit Root Test, Time Series Analysis, Johansen cointegration approach, Bound test and error correction models. The study found that there is a negative and important long-term relationship in Sri Lanka between inflation and economic development.

The data was applied to the cointegration approach, Bound test and error correction models. The study found that there is a negative and important long-term relationship in Sri Lanka between inflation and economic development.

Using data on the annual real GDP and consumer price index for 1985-2005, Saaed (2007) analyzed the relationship between inflation and GDP in Kuwait. The projected outcome of the ratio indicates that the consumer price index has a good and long-term inverse relationship 
with real GDP in Kuwait. On the basis of annual data from 1973-2000, Mubarik (2005) estimated Pakistan's inflation threshold.

In four South Asian economies, Malik and Chowdhury (2001) analyzed the short- and longterm dynamics of the inflation-GDP relationship: Bangladesh, India, Pakistan, and Srilanka. Two motivating results were found by applying co-integration and error correction models to the International Monetary Fund's (IMF) annual financial statistics (IFS) data. Faria and Carneiro (2003) looked at the relationship between inflation and GDP in Brazil, which until recently had to face persistently high inflation. Analyzing the two-variable time series model (i.e., vector auto-regression) with annual data for the period 1980-1995, they found that inflation and GDP.

In a small sample of Asian countries and countries that are members of the Organization for Economic Co-operation and Development (OECD), Malla (2002) performed an empirical study. Adjusted for labor and capital, the findings indicate that despite the first gap, there is a statistically significant negative relationship between GDP and inflation in OECD countries.

The relationship between inflation and GDP was examined by Barro (1997) using a comprehensive study of more than 100 countries between 1960 and 1990. His empirical findings indicate that inflation and GDP have a statistically important negative relationship. Some land features (e.g., fertility rate, schooling, etc are known to be constant.

The nexus between trade and economic development in Italy, Barbara Pistoresi and Alberto Rinaldi (2011), has been widely debated through historiography. However, on this subject, there are no long-term studies covering the entire period from Unification to the present day. This paper tries to fill this void by using cointegration analysis and causality tests to examine the relationship between actual exports, imports and GDP in Italy from 1863 to 2004 . The result implies that these variables change in the long term, but over time, the direction of causality varies. Import growth led to GDP growth in the period prior to the First World War, which in turn led to export growth. Conversely, we have a clear bi-directionality between imports and exports in the post-Second World War era as a consequence of the rise in intra-industry trade. Weak support is also seen for export-led growth and growth-driven imports. This means that exports have not been the primary or principal engine of economic development. There were undoubtedly a variety of factors at work, among which high rates of capital accumulation and the distribution of internal demand were likely to have stood out.

Bruno and Easterly (1999) examined GDP drivers using annual consumer price inflation in 26 countries that experienced an inflation crisis from 1961-1992. According to their empirical analysis, the inflation rate is $40 \%$. And more on the eve of the inflation crisis. In their view, the relationship between inflation and GDP is inconsistent or somewhat unclear below this threshold when countries with a high inflation crisis are excluded from the sample.

It can be assumed that according to the nature of the studied country generally trade liberalization or generally trade reforms have different effects on the industry; the current literature and empirical evidence could never state a consistent causality relationship entirely 
on the causality relationship between economic development, GDP, export and import growth. A unilateral relationship is represented in some studies and a shared relationship in others.

\subsection{DATA SOURCES \& DESCRIPTION}

\section{SAMPLE SIZE}

The data used in this study are mainly time series of annual data covering the periods 19822019. Thus, the sample size is 37 . The three economic variables included in the study are exports, imports and inflation. These are indicators for measuring GDP.

\section{SAMPLING UNIT}

I have selected the data set consists of observations

- GDP (in US dollars)

- Goods Exports of goods and services (in US dollars)

- Imports of goods and services (in US dollars) and

- Inflation (as a percentage).

\section{SAMPLE SOURCE}

All data sets are taken from world development indicators. From the online version of the World Databank.

\section{DATA DESCRIPTION}

GDP, imports and exports for the period 1982-2019 are shown in the table below 
Figure 1. Macroeconomic Determinants (GDP, Inflation, Export and Import) Relationship

100.00

80.00

Gr

OW 60.00

th

$\% \quad 40.00$

$\% \quad 20.00$

0.00

$-20.00$

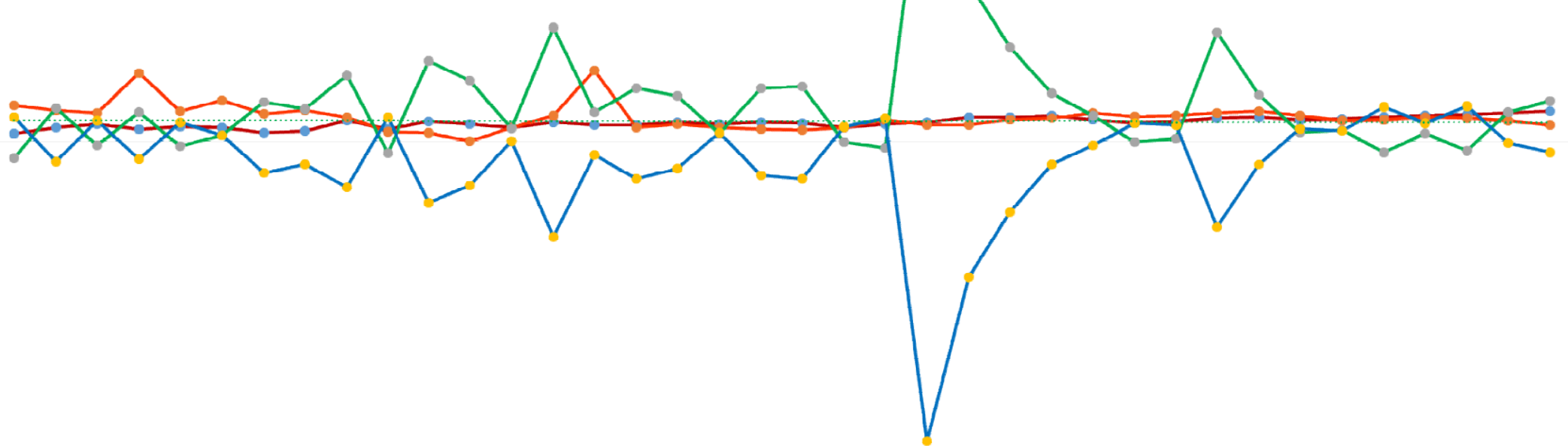

$-80.00$

Year

$-100.00$

198198198198198198198198199199199199199199199199199199200200200200200200200200200200201201201201201201201201201201 $\begin{array}{llllllllllllllllllllllllllllllllllllllllllllll}2 & 3 & 4 & 5 & 6 & 7 & 8 & 9 & 0 & 1 & 2 & 3 & 4 & 5 & 6 & 7 & 8 & 9 & 0 & 1 & 2 & 3 & 4 & 5 & 6 & 7 & 8 & 9 & 0 & 1 & 2 & 3 & 4 & 5 & 6 & 7 & 8 & 9\end{array}$

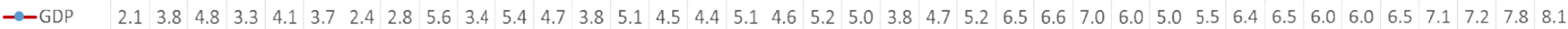

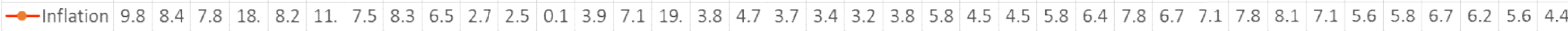

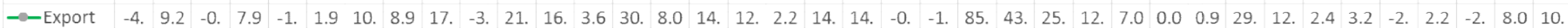

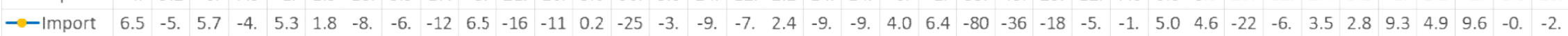

Source: World Bank 


\subsection{THE OUTPUT OF GROWTH DOMESTIC PRODUCT (GDP)}

With strong macroeconomic fundamentals, the economy of Bangladesh has achieved sustained growth. The GDP growth rate has consistently remained above 6 percent over the last five years. Higher per-capital GDP growth, particularly since the late 1990s. The following table shows a few years of GDP growth.

Figure 2. GDP Growth Rate

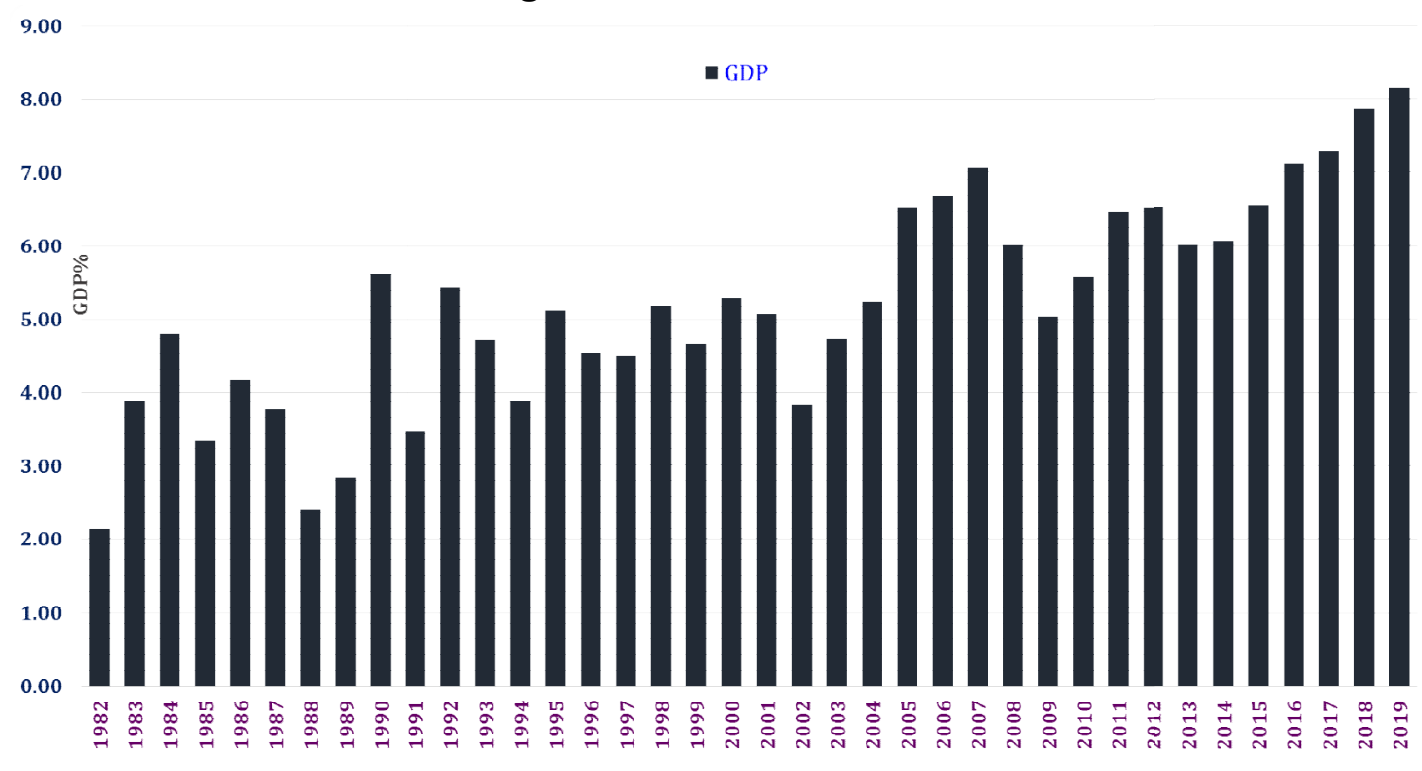

Source: World Bank

Bangladesh's exports declined to 217.66 BDT trillion in August from 231.31 BDT trillion in July 2020.

Figure 3. Bangladesh Exports

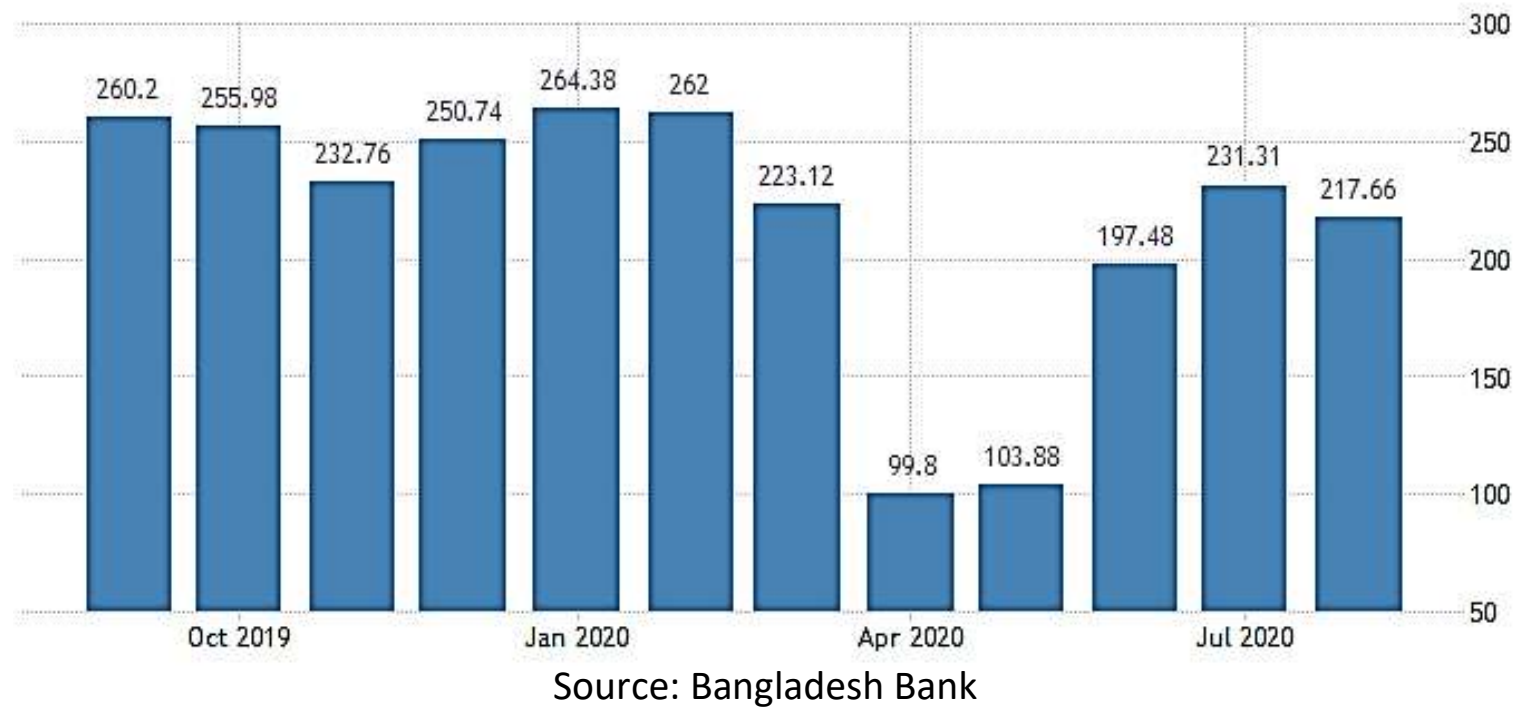


Table 1. Major Export Commodities EXPORT RECEIPTS OF BANGLADESH BY MAJOR COMMODITIES

\begin{tabular}{|l|r|r|r|r|r|r|}
\hline Year/ Commodities & $2017-2018$ & $\begin{array}{r}\% \text { of } \\
\text { Total }\end{array}$ & $2016-2017$ & $\begin{array}{r}\% \text { of } \\
\text { Total }\end{array}$ & $2015-2016$ & $\begin{array}{r}\% \text { of } \\
\text { Total }\end{array}$ \\
\hline Knit Wear & 105713.9 & $48.1 \%$ & 93087.9 & $46.9 \%$ & 90272.2 & $46.5 \%$ \\
\hline Woven Garments & 79697.9 & $36.3 \%$ & 73673.2 & $37.1 \%$ & 72848.3 & $37.5 \%$ \\
\hline Jute and Jute Manufactures & 7436.6 & $3.4 \%$ & 7497.7 & $3.8 \%$ & 6956.4 & $3.6 \%$ \\
\hline Leather and Leather Manufactures & 5805.8 & $2.6 \%$ & 6232.9 & $3.1 \%$ & 6496.9 & $3.3 \%$ \\
\hline Fish, Shrimps and Prawns & 4087.7 & $1.9 \%$ & 3679.8 & $1.9 \%$ & 3559.2 & $1.8 \%$ \\
\hline Home Textile & 3827.0 & $1.7 \%$ & 3001.1 & $1.5 \%$ & 3273.4 & $1.7 \%$ \\
\hline Vegetable Products & 872.7 & $0.4 \%$ & 971.2 & $0.5 \%$ & 1121.9 & $0.6 \%$ \\
\hline Pharmaceutical Products & 988.4 & $0.4 \%$ & 702.3 & $0.4 \%$ & 577.9 & $0.3 \%$ \\
\hline Plastic and Plastic Products & 607.0 & $0.3 \%$ & 586.6 & $0.3 \%$ & 487.1 & $0.3 \%$ \\
\hline Bicycle & 358.0 & $0.2 \%$ & 432.3 & $0.2 \%$ & 341.9 & $0.2 \%$ \\
\hline Petroleum and Petroleum Products & 80.2 & $0.0 \%$ & 136.1 & $0.1 \%$ & 220.5 & $0.1 \%$ \\
\hline Others & 10176.9 & $4.6 \%$ & 8373.8 & $4.2 \%$ & 8061.6 & $4.2 \%$ \\
\hline Total & 219652.2 & 100.0 & 198374.9 & 100.0 & 194217.3 & 100.0 \\
\hline
\end{tabular}

Source: Bangladesh Bank

Figure 5. Major Countries Export

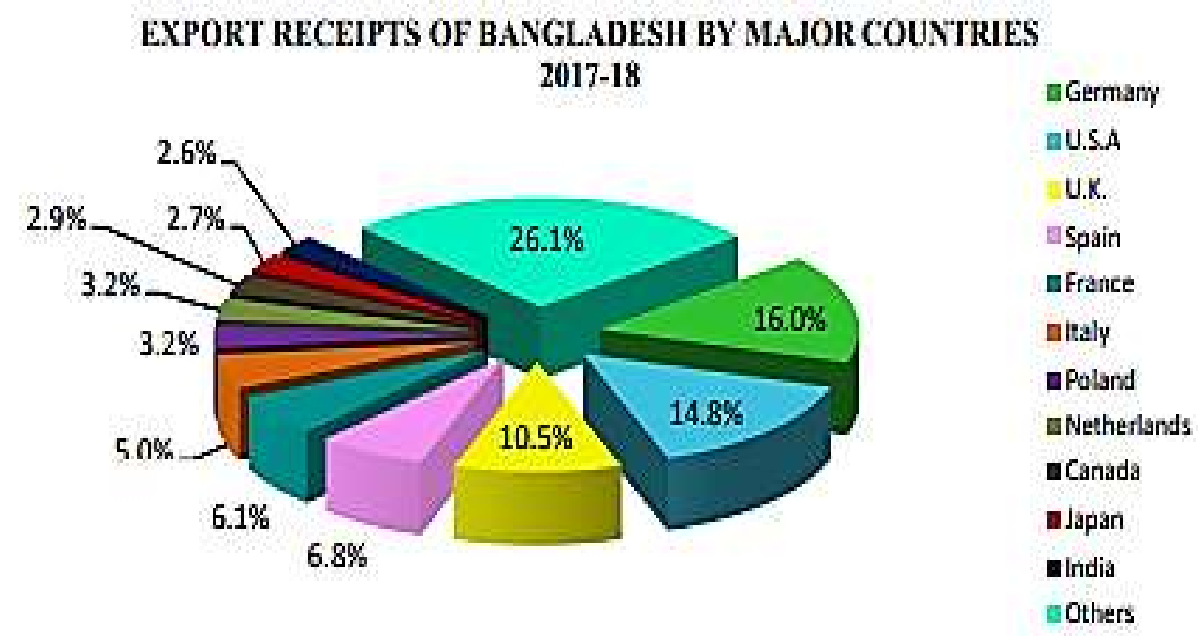

Source: Bangladesh Bank 
Table 2. Current inflation

\begin{tabular}{|l|c|c|c|}
\hline $\begin{array}{c}\text { Rate of Inflation } \\
\text { (as measured by CPI, base 2005-06) }\end{array}$ & October, 2020 & September, 2020 & October, 2019 \\
\hline Point to point & $6.44 \%$ & $5.97 \%$ & $5.47 \%$ \\
Monthly Average(Twelve Month) & $5.77 \%$ & $5.69 \%$ & $5.50 \%$ \\
\hline
\end{tabular}

Source: BBS (Bangladesh Bureau of Statistics)

\subsection{METHODOLOGY}

Zivot \& Wang (2003), the estimation methodology employed in this study is the integration and VAR modeling technique. The entire estimation procedure consists of three steps.

- Unit Root Test,

- Johansen Co-integration Test,

- Vector Autoregressive Model (VAR).

Augment Dickey-Fuller tests are using to examine the stationary of variables in question. Many macroeconomic variables in time series are no stationary. If a series is stationary, then the shock imposed on is the elimination, and variable returns to its long-term equilibrium. On the other hand, if the time series is non-stationary, the mean or variance or both are a function of time. And if the time is infinite, varying the variables will be infinite. Therefore, the variable will be divergent away from its path equilibrium.

Johansen Co integration Test is using because we do not know either those variables have a long-run association or short-run association. If those variables have a long-run association, we can run the Vector Error Correction Model (VECM). And if those variables have a short-run association, we can run the Vector Autoregressive Model (VAR).

Vector Autoregressive Model (VAR) is using to examine the independent variables are significant or not significant. That means they reject or accept the null hypothesis. The negative or positive relationship between the dependent and independent variables. The model is significant or not.

\section{FORMULATION OF GENERAL MODEL}

This study examines the relationship between GDP, Export, Import, and inflation in Bangladesh. Annual data on real GDP, export, import, inflation from 1982 to 2016 were used for this paper.

The primary model showing the relationship among GDP, Export, Import, and inflation in Bangladesh can be specified thus:

GDP $=\beta 1+\beta 2$ export $+\beta 3$ import $+\beta 4$ inflation $+\varepsilon$

Where: 
Dependent variable: GDP

Independent variable: Export, Import \& Inflation.

Here, $\beta 1$ is the constant term and $\varepsilon$ is the random error term assumed to be normal, identically, and independently distributed. Here, $\beta 2, \beta 3$, and $\beta 4$ represent the coefficient of regression.

The model can also be represented in thus format:

In GDP $=\beta 1+\beta 2$ In export $+\beta 3$ In import $+\beta 4$ In inflation $+\varepsilon$ In GDP $=\beta 1+\beta 2$ export $+\beta 3$ import $+\beta 4$ inflation $+\varepsilon$

$\mathrm{GDP}=\beta 1+\beta 2 \ln$ export $+\beta 3 \ln$ import $+\beta 4$ In inflation $+\varepsilon$

\subsection{EMPIRICAL ANALYSIS}

\section{UNIT ROOT TEST}

G. A., Libanio, (2005) proposed that data from the macroeconomic time series is normally characterized by a stochastic pattern that can be eliminated by differentiation. Some variables on levels are stationary, others after one differentiation become stationary, and some may become stationary by more than one differentiation. Analysis is most important for any econometrics, expecting whether or not we need to verify the data stationary. If the knowledge is not stationary, it is because we are going to object.

The Augmented Dickey-Fuller (ADF) technique was used for the stationary evaluation of the variables. In the case of the Dickey-Fuller Test, an autocorrelation problem can occur.

To tackle the autocorrelation problem, Dickey-Fuller have developed a test called Augment Dickey-Fuller Test (three models).

1. Model One: Intercept Only

2. Model Two: Trend \& Intercept

3. Model Three: No Trend \& Intercept

First Dickey-Fuller Model has only intercepted. Second Dickey-Fuller Model has both trends \& intercept \& the third Dickey-Fuller Model has no trend and intercept. So, there are three Dickey-Fuller models. We want to check whether our variables have unit root or not which means stationary or not. We also want to check all three models come to the same decision all the time. Otherwise, we need differentiation.

ADF test was applied to the series and the following findings were obtained. The $5 \%$ significance level was taken into account in the analysis. When the absolute value of test statics is more than the critical value, we can reject the null hypothesis. But if when the absolute value of test statics is less than the critical value, we cannot reject the null hypothesis. That is always a guideline.

Model One (Intercept Only)

Time variable: year, 1982 to 2019

Delta: 1 year

dfuller gdp, regress lags(0)

Dickey-Fuller test for unit root Number of obs. $=34$ 


\begin{tabular}{ccccc}
\hline & Test & $\mathbf{1 \%}$ Critical & $\mathbf{5 \%}$ Critical & $\mathbf{1 0 \%}$ Critical \\
\hline $\mathrm{Z}(\mathrm{t})$ & 8.608 & -3.689 & -2.975 & -2.619 \\
\hline MacKinnon & &
\end{tabular}

MacKinnon approximate $p$-value for $Z(t)=1.0000$

Model Two (Trend \& Intercept)

Time variable: year, 1982 to 2019

Delta: 1 year

dfuller gdp, trends regress lags(0)

Dickey-Fuller test for unit root

Number of obs. $=34$

\begin{tabular}{|c|c|c|c|c|}
\hline & Test & $1 \%$ Critical Value & $5 \%$ Critical Value & $10 \%$ Critical Value \\
\hline$Z(t)$ & 4.332 & -4.297 & -3.564 & -3.218 \\
\hline \multicolumn{5}{|c|}{ MacKinnon approximate $p$-value for $Z(t)=1.0000$} \\
\hline \multicolumn{5}{|c|}{ Model Three (No Trend \& Intercept) } \\
\hline \multicolumn{5}{|c|}{ Time variable: year, 1982 to 2019} \\
\hline \multicolumn{5}{|c|}{ Delta: 1 year } \\
\hline \multicolumn{3}{|c|}{ Dickey-Fuller test for unit root } & nber of obs. $=34$ & \\
\hline & $\begin{array}{c}\text { Test } \\
\text { Statistics }\end{array}$ & $\begin{array}{c}1 \% \text { Critical } \\
\text { Value }\end{array}$ & $\begin{array}{l}5 \% \text { Critical } \\
\text { Value }\end{array}$ & $\begin{array}{c}10 \% \text { Critical } \\
\text { Value }\end{array}$ \\
\hline$Z(t)$ & 11.076 & -2.646 & -1.95 & -1.604 \\
\hline
\end{tabular}

MacKinnon approximate $\mathrm{p}$-value for $\mathrm{Z}(\mathrm{t})=1.0000$

Model One

We find that the absolute value of test statics is 8.068 which is greater than the test critical value of $5 \%$. So we can reject the null hypothesis which is the level (Intercept only) of GDP does not have unit root and conclude that the data is stationary.

Model Two

We find that the absolute value of test statics is 4.332 which is greater than the test critical value of $5 \%$. So we can reject the null hypothesis which is the level (Trend \&Intercept) of GDP does not have unit root and conclude that the data is stationary.

Model Three

We find that the absolute value of test statics is 11.076 which is greater than the test critical value $5 \%$. So we can reject the null hypothesis which is the level (No Trend \&Intercept) of GDP does not have unit root and conclude that the data is stationary.

Finally we say that all the three model came to same decision that GDP does not have unit root. That means the data is stationary.

\subsection{JOHANSEN CO-INTEGRATION TEST}

We have to estimate the VAR model or VECM and we have four variables such as GDP, Export, and Import \& Inflation. We should run the Johansen Co-integration Test because we do not know either those variables have a long-run association or shortrun association. If those variables have a long-run association, we can run the Vector Error Correction Model (VECM). And if those variables have a short-run association, we can run the Vector Autoregressive Model (VAR). 
When the absolute value of test statics is more than the critical value, we can reject the null hypothesis. That means there is co-integration, meaning that long-run association among those variables. But when the absolute value of test statics is less than the critical value, we cannot reject the null hypothesis. There is no co integration, meaning that short-run association among those variables. That is always a guideline.

Johansen tests for co-integration

Trend: constant

Number of obs. $=32$

Sample: 1985 - 2019

Lags $=3$

Table 3. Johansen Co-integration Test

\begin{tabular}{cccccc}
\hline Maximum & parms & LL & Eigenvalue & Trace & 5\% Critical \\
\hline 0 & 36 & - &. & $35.6199 *$ & 47.21 \\
1 & 43 & - & 0.44003 & 17.064 & 29.68 \\
2 & 48 & - & 0.35534 & 3.015 & 15.41 \\
3 & 51 & - & 0.08981 & 0.0037 & 3.76 \\
4 & 52 & - & 0.00012 & & \\
\hline
\end{tabular}

Table 4. Johansen Co-integration Test

\begin{tabular}{cccccc}
\hline Maximum & parms & LL & Eigenvalue & Trace & 5\% Critical \\
\hline 0 & 36 & -2181.6669 &. & 18.5559 & 27.07 \\
1 & 43 & -2172.3889 & 0.44003 & 14.049 & 20.97 \\
2 & 48 & -2165.3645 & 0.35534 & 3.0113 & 14.07 \\
3 & 51 & -2163.8588 & 0.08981 & 0.0037 & 3.76 \\
\hline
\end{tabular}

Here the maximum rank 0 is the null hypothesis. We find that the value of test statics is 35.6199 which is less than the test critical value of $5 \%$. So we cannot reject the null hypothesis. There is no co-integration, meaning that short-run association among those variables.

Similarly, the value of max statics is less than the test critical value of $5 \%$. So we cannot reject the null hypothesis, meaning that there is no co-integration \& short-run association among four variables such as GDP, Export, Import, and Inflation.

So we can see that test statics and max statics, they are telling the same thing that variables are not co-integrated. So we can run unrestricted Vector Autoregressive Model instead of Vector Error Correction Model.

\subsection{VECTOR AUTOREGRESSIVE MODEL}

We have seen that our four variables such as GDP, Export, Import, and Inflation are not co-integrated. So we can run unrestricted Vector Autoregressive Model.

Time variable: year, 1982 to 2019

delta: 1 year 
. var gdp, lags(1/3) exog(Export-Import inflation)

Vector auto regression

Sample: 1985 - 2019

No. of obs. $=35$

\begin{tabular}{cccccc}
\hline Equation & Parms & RMSE & R-sq & chi2 & P>chi2 \\
\hline gdp & 7 & $2.60 E+09$ & 0.997 & 9524.92 & 0
\end{tabular}

Log likelihood $=-735.6776$

$\mathrm{AIC}=46.41735$

$\mathrm{FPE}=8.50 \mathrm{E}+18$

$\mathrm{HQIC}=46.52363$

Det (Sigma_ml) $=5.45 \mathrm{E}+18$

$\mathrm{SBIC}=46.73798$

Table 5. Vector Autoregressive Model

\begin{tabular}{|c|c|c|c|c|c|c|}
\hline gdp & Coef. & Std. Err. & $z$ & $P>|z|$ & \multicolumn{2}{|c|}{ [95\% Conf. Intervall } \\
\hline L1. & 1.140824 & 0.1573635 & 7.25 & 0 & 0.8323971 & 1.449251 \\
\hline L2. & -0.4261484 & 0.231024 & 1.84 & 0.065 & -0.8789472 & 0.0266503 \\
\hline L3. & 0.4362815 & 0.1720054 & 2.54 & 0.011 & 0.099157 & 0.773406 \\
\hline Export & 1.079204 & 1.607883 & 0.67 & 0.502 & -2.072189 & 4.230597 \\
\hline Import & -0.2759896 & 1.049644 & 0.26 & 0.793 & -2.333253 & 1.781274 \\
\hline inflation & $3.94 \mathrm{E}+08$ & $1.15 E+08$ & 3.44 & 0.001 & $1.69 E+08$ & $6.18 \mathrm{E}+08$ \\
\hline _cons & $-5.42 E+09$ & $1.28 \mathrm{E}+09$ & $\begin{array}{c}- \\
4.22 \\
\end{array}$ & 0 & -7.93E+09 & $-2.90 \mathrm{E}+09$ \\
\hline
\end{tabular}

\subsection{VECTOR AUTOREGRESSIVE ANALYSIS}

\section{SLOPE COEFFICIENT}

The slope coefficient of approximately 1.079 means that if exports increase by $\$ 1$, GDP would increase by approximately $\$ 1.079$. The slope coefficient of approximately 0.275 means that if imports increase by $\$ 1$, GDP will decrease by approximately $\$ 0.275$. The slope coefficient of approximately 3.94 means that if inflation rises by $\$ 1$, GDP will grow by approximately $\$ 3.94$.

\section{SIGNIFICANT TEST}

Export is not important since the 50.2 percent $p$-value is greater than 5 percent, which means that export is not an important variable to describe GDP. Importing is not necessary because 79.3 percent of the $p$-value is greater than 5 percent. To describe GDP, it is not a significant variable. Inflation is important because its 0.1 percent $p$-value, which 
is greater than 5 percent, means that inflation is an important variable that explains GDP. There is a lack of research on the effect of exports, imports and inflation on Bangladesh's economic development. The current scenario of the effects of exports, imports \& inflation on GDP is shown in this report. This is why this study is not that significant. For Export \& Import, this study found that an alternative hypothesis is valid. For inflation, the null hypothesis holds.

\section{R SQUARED}

For R-squared, the optimal amount is 0.80 . But I did find R -squared $=0.9967$ in the regression analysis. It is greater than the amount desired. The R-squared value of about 0.99 means that our three independent variables such as export \& import and inflation will jointly explain the 99 percent difference in GDP. And another variable that is not export \& import and inflation will explain the remaining $1 \%$ of the GDP variance. This is a nicely-created model. The data or variable is a good match.

\section{REGRESSION MODEL IS GOOD FIT}

The chance value, which is less than 0.05 , is 0.000 . So we're suggesting that it's critical that exports, imports, and inflation will jointly affect the population's GDP. We also conclude that the model is a good match according to the R-the square value and we can thus reject the null hypothesis.

\subsection{POLICIES}

\subsection{SIGNIFICANT CHARACTERISTICS OF EXPORT POLICIES ARE}

i) Improving the quality of goods; encouraging the use of new, suitable and environmentally sustainable technologies; promoting the manufacture of highend products and improving the design of products.

ii) To improve the quality of the goods; to promote the use of new, sufficient and environmentally sustainable technologies, to manufacture high-end products and to improve the design of the products.

iii) Support the development of the necessary infrastructure, particularly for backward and forward ties, with a view to promoting the production of exportable goods;

iv) Ensuring the availability of raw materials for the manufacture of products for export;

v) Providing appropriate guidance on understanding the evolving international trading environment to trade organizations, business associations, business people and related persons, etc. 
vi) Increasing the competitiveness and diversity of products;

\subsection{POLICY IMPORTATION}

i. to phase out the embargo on manufactured products to promote the availability of industrial raw materials and to improve competitiveness and efficiency;

ii. To ensure the distribution, on an emergency basis, of vital commodities in the national interest;

iii. Offering facilities for the implementation of technical innovation to cope with new technological expansion;

iv. To liberalize the import policy in the sense of globalization and an open market economy;

v. Provision of a qualitative and healthy product;

vi. Increase indigenous exports through the facilitation of backward linkages for local industries;

\subsection{RECOMMENDATION}

For Bangladesh, the findings of the analysis have useful implications. To improve economic growth in Bangladesh, one significant suggestion is to place more emphasis on private investment. This variable must therefore be emphasized by the Bangladeshi Authority in order to promote and stimulate economic growth in Bangladesh. Building more wealth or creating more jobs is one of the ways to achieve this policy goal.

Import Investment (I.I.) > Export Earnings (E.E.) $=$ Not Favorable Trade Balance

\section{If, Export Earnings (E.E.) > Import Investment (I.I.) = Favorable Trade Balance}

Means, In Bangladesh, import investment is higher than export earnings. For this reason, there is no favorable trade balance. The following steps should be taken to fix the problems. Exports from Bangladesh must keep pace with the expected growth of 7 percent of GDP and contribute to this by rising export earnings. In this exercise, new thrust sectors must be defined, production costs reduced, higher exports of higher value added products increased, product wise diversified, product quality ensured, packaging improved, efficient productivity achieved, export-oriented industry developed, infrastructure growth, small cottage industry modernization. We should aim at selling quality goods at reasonable price at stipulated time. The export trade in Bangladesh is characterized by the dominance of a few commodities in a narrow market. For economic growth, such reliance on a small number of export products aimed at a few limited markets is not desirable. Consequently, the country must aim at diversifying both goods and markets, or else our export trade will become stagnant in the near future.

For a favorable trade balance in Bangladesh, well-planned strategies are important. For these purposes, the following policies are being pursued to achieve the export and import policy objectives: Simplifying export processes and helping to achieve productivity in the 
private sector. Increased private sector engagement by the government should be supported when the government is involved. Its facilitating position will continue to play. Improving the technical strength and efficiency of exportable goods and promoting cost reduction, achieving globally agreed levels of quality and thereby consolidating their competitiveness. In order to minimize import spending, importing alternative industries such as local raw material-based industries should be developed. In addition to these, the quantity of importable luxury items such as luxurious perfume, trendy products, luxury cars, etc. should be limited. Regulated import policies should be followed instead of liberal import policies.

\section{CONCLUSION}

In the literature, very few studies investigating the relationship between exports, imports, inflation, and GDP have used annual data. This work was carried out for the first time, to the best of the author's knowledge, using the STATA test, based on the annual data recorded for the period 1982-2016. It is seen from our empirical findings that the paper evaluated the series using the ADF test for stationary, and the variable proved to be integrated from order one and found that the series is stationary at the level and some are stationary after differentiating one. The unregulated Vector Autoregressive Model (VAR) found that exports had a positive and negligible effect on Bangladesh's GDP. The value of Bangladesh's GDP has a negative and insignificant impact. And there is a positive \& important impact of inflation on that. The model is a good match, so I reject the null hypothesis and support the hypothesis of the alternative.

Because this analysis only covers four variables, in the future there is a range to cover more variables. In Bangladesh, when we analyzed the effect of exports, imports \& inflation on GDP, we expected exports to be positive, significant and imports to be negative \& negligible. In addition, the study results show that exports and imports are negligible, but inflation is important for Bangladesh's economic growth. There is therefore, space for further research on this topic. 


\section{REFERENCES}

Abou-Stait, F. (2005). Are Exports the Engine of Economic Growth? An Application of Cointegration and Causality Analysis for Egypt, 1977-2003. African Development Bank. Economic Research Working Paper.

https://www.afdb.org/fileadmin/uploads/afdb/Documents/Publications/00363566-EN-ERWP76.PDF

Afaf Abdull J. Saaed and Majeed Ali Hussain (2015). Impact of Exports and Imports on Economic GDP from Tunisia. Journal of Emerging Trends in Economics and Management Sciences (JETEMS) 6(1):13-21.

Ahmed, H. A., \& Uddin, M. G. S. (2009). Export, Imports, Remittance and Growth in Bangladesh: An Empirical analysis. Trade and Development Review. 2(2), 70-84.

Akbar, M. and Naqvi, Z.F. (2000). Export Diversification and the Structural Dynamics in the Growth Process: The Case of Pakistan, The Pakistan Development Review, Vol.39, No.4, pp.573-589.

Akhter, M. (2015). The Impact of Export and Import on Economic GDP in Bangladesh. World Vision, 9(3).

Atrkar roshan, S. (2008). Export expansion and GDP, evidences of Iran after the revolution period: Journal of Social and Human Sciences. Vol.26, Issue: 11.

Aziz, R. N. A. R., and Azmi, A. (2017). Factors affecting gross domestic product (GDP) growth in Malaysia. International Journal of Real Estate Studies, 11(4), 61-67. Available at: https://www.utm.my/intrest/files/2017/09/07-FACTOR-AFFECTING-GROSS-DOMESTICPRODUCT-GDP-GROWTH-IN-MALAYSIA1.pdf

Bangladesh Bank (2020). Available at: https://www.bb.org.bd/econdata/index.php Bangladesh Bureau of Statistics (BBS) (2020). Available at: http://203.112.218.65:8008/

Bahmani-Oskoee, M and J. Alse (1993). Export Growth and Economic Growth: An application of Cointegration and Error-Correction Modelling. Journal of Development areas. Vol. 27: 535-542.

Bahmani-Oskooee, M. and Domac, I. (1995). Export Growth and Economic Growth in Turkey: Evidence Counteraction Analysis. METU Studies in Development. Vol.22, pp. 67-77.

Balassa, B. (1978). Exports and GDP: Further Evidence. Journal of development Economics. Vol. 5: $181-189$.

Barro R. J., (1997). Determinants of Economic Growth : a Cross-Country Empirical Study. NBER Working Paper 5698.

Bruno, M., and Easterly, W. (1999). Inflation Crises and Long-Run Growth. World Bank Policy \&Research. Working Paper No.1517.

Bruno, Michael, and William Easterly. (1998). Inflation Crises and Long-Run Growth. Journal of Monetary Economics. 41, 3-26.

Cetinkaya, M. and S. Erdogan (2010). Analysis of the Relation between GDP, Import and Export. International Research Journal of Finance and Economics. Vol.55.

Chien-Hui Lee and Bwo-Nung Huang (2002). The relationship between export and economic growth in East Asian countries. Journal of Economic Development .V-27, No-02.

Clarke, J. A and Ralhan, M. (2005). Direct and Indirect Causality between Exports and GDP from Bangladesh and Sri Lanka: Horizon Matters. Econometrics Working. Retrieved at https://www.uvic.ca/socialsciences/economics/assets/docs/econometrics/ewp0512.pdf

E. Zivot et al. (2003). Modeling Financial Time Series with S-Plus. Available at: https://link.springer.com/chapter/10.1007\%2F978-0-387-21763-5 4 
Erbaykal, E. and Okuyan, H. (2008). Does inflation depress economic growth? Evidence from Turkey. International Research Journal of Finance and Economics, 17: 40-48. Available: http://ssrn.com/abstract $=1288783$

Faria, J. R. and Carneiro, F.G. (2003). Does High Inflation Affect Growth in the Long and Short run? Journal of Applied Economics. Vol. IV, No. 1, pp. 89-105.

Feder, G. (1982). On Exports and GDP. Journal of Development Economics, Vol. 12: 59-73.

Giles, J. A., \& Williams, C. L. (2000a). Export-led growth: a survey of the empirical literature and some non-causality results: Part 1 . Journal of International Trade and Economic Development. 9(3), 261-337.

Hatemi, J. A. (2002), Export Performance and Economic Growth Nexus in Japan: A Bootstrap Approach. Japan and the World Economy. 14, 25-33.

Jayathileke, P. and Rathnayake, R. (2013). Testing the link between inflation and economic growth evidence from asia. Modern Economy, 4: 87-92. Available: https://m.scirp.org/papers/28180

Love, J., \& Chandra, R. (2005). Testing export-led growth in Bangladesh in a multivariate VAR framework. Journal of Asian Economics, 15(6), 1155-1168. doi: 10.1016/j.asieco.2004.11.009

Malik, G. and Chowdhury, A. (2001). Inflation and economic growth: Evidence from four South Asian countries. Asia-Psific Development Journal, 8(1): 123-35.

Mofrad, M.A. (2012). The relationships between GDP, export and investment: case study Iran.

Mubarik, Y. (2005). Inflation and growth, An estimate of threshold level of inflation in Pakistan. State Bank of Pakistan - Reserve Bulletin, 1(1): 35-44.

Available at: https://econpapers.repec.org/article/sbpjournl/03.htm

Mucahit Aydin \& Murat Sari. (2014). Relationship between GDP and export in Turkey. Information Society and Sustainable Development.

Mukit, M., \& Islam, M. (2018). The emergent impact of internet banking espousal in Bangladesh opportunity hitch. International Journal of Innovative Science and Research Technology (IJISRT). 3(12), 535-539. Retrieved at https://ijisrt.com/the-emergent-impactof-internet-banking-espousal-in-bangladesh-opportunity-hitch

Pistoresi, B., and A. Rinaldi, 2011. Exports, imports and growth: University di Modena e Reggio Emilia, Department di Economia Politica and ReCent, Via Berengario., 51: 11.

Rahmaddi, R., \& Ichihashi, M. (2011). Exports and economic growth in Indonesia: A causality approach based on multi-variate error correction model. Journal of International Development and Cooperation, 17(2), 53-73. Retrieved at https://ir.lib.hiroshimau.ac.jp/en/list/HU journals/AN10482914/17/2/item/31352

Saaed, A. (2007). Inflation and economic growth in kuwait: 1985-2005 evidence from cointegration and error correction model. Applied Econometrics and International Development, 7(1): 143-55.

Shirazi, N. S., \& Manap, T. A. A. (2005). "Export-led growth hypothesis: Further econometric evidence from South Asia". The Developing Economies, 43(4), 472-488.

Shihab, R. A., Soufan, Thikraiat, \& Abdul-Khaliq, S. (2014). The Causal Relationship between Exports and GDP in Jordan. Global Journals, 14(1). https://globaljournals.org/item/2973the-causal-relationship-between-exports-and-economic-growth-in-jordan

Sultan, P. (2008). Trade, Industry and Economic Growth in Bangladesh-SESRIC. Journal of Economic Cooperation, 29(4), 71-92.

Tinh, D. P. T. (2012). The transition of Vietnam's model of economic growth. American International Journal of Contemporary Research, 2(6), 66-71. 
Ullah, S., 2009. Cointegration and causality between exports and economic growth in Pakistan. European Journal of Social Sciences 10(2), 264-272.

Yuhong Li, Zhongwen Chen, Changjian San (2010). Research on the relationship between foreign trade and the GDP growth of East China - Empirical Analysis based on Causality, Modern Economy. 1, 118-124. Retrieved from http:// www. SciRP.org/journal/me. In text citation: Yuhong Li, Zhongwen Chen, Changjian San (2010) 